\title{
Self-perceived Non-nativeness in Prospective English Teachers' Self-images ${ }^{1}$
}

\section{A autopercepção da Não-natividade na Autoimagem dos Futuros Professores de Inglês}

John Jairo Viafara Gonzalez*

Universidad Pedagógica y Tecnológica de Colombia

Boyacá, Colômbia

\begin{abstract}
The native speaker fallacy has been identified as one of the most prevailing and harmful language ideologies to affect non-native speaker teachers (NNSTs) around the world. By examining how participants' self-perceived nonnativeness shape their self-images as prospective English teachers in Colombia, this mix-method study seeks to contribute to expand this body of research in the Latin American context. Findings in this study revealed a dichotomy in participants' self-perceptions: though they do not regard their non-nativeness as a potential problem in their future careers because of their ongoing education and their advantages as NNSTs, they see themselves in an unfavorable position compared to native speaker teachers concerning their "non-ideal language ability and cultural knowledge."
\end{abstract}

Keywords: Language ideologies; Non-Native English Speaker Teachers; Myth of the Native Speaker; Native Speaker Fallacy; Self-perceived (non) Nativeness.

Resumo: A falácia do falante nativo tem sido identificada como uma das ideologias mais prevalentes e prejudiciais a afetar os professores falantes nãonativos (NNSTs). Através da análise de como a autopercepção da não-natividade dos participantes forma sua autoimagem como futuros professores de inglês na Colombia, este estudo envolvendo métodos mistos procura contribuir para expandir esse corpo de pesquisa no contexto da América Latina. Resultados deste estudo revelaram uma dicotomia na autopercepção dos participantes: embora eles não considerem a sua não-natividade como um problema em potencial nas suas carreiras futuras, por causa da sua educação continuada e suas vantagens como NNSTs, em relação aos professores nativos, os NNSTs se veem em uma

* john.viafara@uptc.edu.co

${ }^{1}$ This article is based on the authors' three-article Ph.D. dissertation called "Selfperceived (non) Nativeness and Colombian Prospective English Teachers in Telecollaboration," which specifically focuses on the first article included in the dissertation document. 
posição desfavorável por sua "habilidade de língua e conhecimento cultural não-ideais".

Palavras-chave: Ideologias da Linguagem; Professores de Inglês Não-Nativos, Mito do Falante Nativo; Falácia do Falante Nativo; Autopercepção da (não) Natividade.

\section{Introduction}

Since the emergence of Paikeday's (1985) seminal work, "The Native Speaker is Dead", a robust number of publications have campaigned against the myth of the native speaker and the native speaker fallacy. These ideologies promote an idealized native speaker as the appropriate model for language proficiency and language teachers' pedagogical ability, as well as justify social sanctions for those students and teachers with no native-like credentials.

Foreign language education has been constructed under the premise that learners' instruction should enable them to interact primarily with native speakers (KACHRU and NELSON, 1996; MODIANO, 1999; JENKINS, 2006; COOK, 2007). Traditionally, the materials, syllabi, and standards for evaluation are based upon guidelines that adopt native speaker norms as a benchmark (ALPTEKIN, 2002; MCKAY, 2002; COOK, 2007). Nonetheless, the native speaker standard does not account for the actual variability of speakers at various levels, disenfranchising them from expressing their culture and identity (BRUTT-GRIFFLER and SAMIMY, 2001; COOK, 2007). The idealized native speaker is an inconsistent and biased linguistic construct, and its use as a measure of language ability exposes learners to inescapable failure (RAJAGOPALAN, 1997; KRAMSCH, 2003).

This study joins the efforts of scholars to increase the awareness of, challenge, and dismantle the ubiquitous belief in the native speaker as the goal that students and teachers in the foreign language education field need to accomplish. In this vein, two groups of prospective English teachers attending public Colombian Universities participated in this study. Their survey and interview answers contributed to the researcher's understanding of what their self-perceptions as prospective non-native English speaking teachers (NNESTs) were and how these self-perceptions influenced their views of themselves as prospective English teachers.

This study seeks to contribute to the diversification of NNESTs research. Traditionally NNEST research has focused on in-service teachers and pre-service teachers as students in graduate and post graduate programs 
(BRAINE, 2005; MOUSSU and LLURDA, 2008). Undergraduate preservice teaching, the focus of this exploration, constitutes a fundamental pillar in teacher education, and as such, the study of influential ideologies like nativespeakerism at this stage of these student teachers' education becomes relevant. Thus, prospective teachers can gain awareness of these beliefs, understand their effects, and contribute to dismantling them.

In addition, most research on NNESTs has primarily been conducted in the U.S., Australia, Canada, and the U.K., or in inner circle countries (KACHRU, 1990). In expanding circle countries located in Latin-American, including Colombia, research on NNESTs is scarce at best. Nonetheless, research on language policies evidences that governments in the region are implementing ambitious programs for the teaching of English that usually favor native speakers' status and knowledge over local non-native Colombians (GUERRERO, 2008; USMA, 2009; VALENCIA, 2013). The situation discussed above requires, as Gonzalez (2010, p. 346) explains, more critical applied linguistic approaches in a field, like EFL, that is not "neutral and depoliticized."

\section{Literature review}

\subsection{Nativespeakerism and associated language ideologies}

This section presents and discusses the main constructs informing this study and the research on NNESTs. To begin with, nativespeakerism is a term originally coined by Holliday (2006, p. 1) to denote "the belief that 'native-speaker' teachers represent a 'Western culture' from which springs the ideals both of the English language and of English language teaching methodology." This ideology is intrinsically connected with two other well-established myths in the field of language teaching and learning: the myth of the native speaker (RAMPTOM, 1990; PENNYCOOK, 1994; CANAGARAJAH, 1999; KRAMSCH, 1999) and the native speaker fallacy (PHILLIPSON, 1992; CANAGARAJAH, 1999). This myth and fallacy show a similar ideology from two interrelated perspectives. The myth promotes the belief that those who are regarded as native speakers are ideal language models. The fallacy predicates that teachers who have been granted native speaker credentials are better teachers than those whose nativeness does not correspond to the native speaker ideal. 
Though on the surface this ideology seems to be focused primarily on the evaluation that speakers make of others based on their language use, it transpires that multiple sociocultural and political considerations come to bear when speakers are granted or denied nativeness. Native speaker credentials are granted to those who, for example, are identified as being born in certain western nations (e.g. in the case of English, England, the U.S., and Australia) and reveal particular values and ethnic and racial characteristics associated with privileged classes in these countries.

From a linguistic perspective, this myth aligns with theoretical constructs which are used to describe ideal speakers as producers of "perfect" utterances. Chomsky emphasizes a monolingual ideal speakerlistener possessing a unitary and decontextualized competence which is to a great extent genetically acquired. In this theory, the native speaker possesses natural intuition to produce and make accurate judgments about language. This conceptualization has been identified as an influential academic precursor of the myth of the native speaker (PAIKEDAY, 1985; RAJAGOPALAN, 1997; COOK, 1999; CANAGARAJAH, 1999; DAVIES, 2004; MAHBOOB, 2005).

The conceptualization of the native speaker as an ideal model for language performance has mainly been problematized because it ignores the natural variability of language in sociocultural contexts. Another complicated issue is an individual's perceived degree of nativeness, which hints at the possibility that a non-native speaker could become a native speaker (MAHBOOB, 2005; WHITE and GENESEE, 1996). In the educational field, for instance, it has become commonplace to depict individuals' abilities or expected competence as native-like or near-native.

Coupled with the previous critical perspective, Applied Linguists in the fields of world Englishes (WEs), English as a lingua franca (ELF), and English as an international language (EIL) bring to bear the effect of the changing global scenario on how native and non-native English speakers position themselves and are positioned as proficient users of language. The progressive expansion of speakers of English as a second or foreign language, which is predicted to surpass native speakers within the next 50 years, questions the imposition of native speaker norms on non-native speakers (GRADDOL, 2003).

The myth of the native speaker and the native speaker fallacy are associated with other similar ideologies. Monolingualism, also known 
as "monolingual" bias (KACHRU, 1990; COOK, 1999; BELZ, 2002; MAHBOOB, 2010), "monolingual nativism" (TRAIN, 2011) or "monolingual fallacy" (PHILLSON as cited in CANAGARAJAH, 1999), places the idealized native speaker within an idealized context for its study. and that context is monolingual. Firth and Wagner (1997), Cook (1997), and Belz (2002) and Sayer (2008) discuss ramifications of these ideologies concerning the negative stigma placed upon the use of L1 in L2 classrooms and the mixture of languages, as well as the traditional focus of second language acquisition research on monolingual speakers, ignoring the bilingual or multilingual nature of a learners' endeavor.

Native Speaker Standard Language (TRAIN, 2007; 2011) emphasizes the connection between two well-established ideologies: nativespeakerism and standardization. For this author, standardization emanates from the language variety associated with native speakers. In this vein, it is the variety of a privileged group. However, it is relevant to clarify that the group supposed to be the model for the standard does not include all those considered native speakers on the grounds of birth. Only the educated native speakers exhibit the standard. The ideology of standardization is seen as the locus of the prescriptivism and purism which "frames variability and diversity as a supposed problem" (TRAIN, 2007), in turn promoting discrimination, as it privileges certain language varieties while others are misrepresented as lower, inappropriate, defective, and undesirable.

The myth of "Non-accent" is another ideology inextricably connected with standardization (LIPPIN-GREEN, 1997). This ideology is rooted in the belief that standard language speakers do not exhibit an accent. Nonetheless, all speakers have an accent, given that accents reveal the normal variation in language according to various sociocultural variables. Regarding second language learners, a wide spread belief is that language learners' L1 accent, when transferred into L2, deems their L2 speech incomprehensible. Though it is undeniable that a different pronunciation of specific sounds or intonation patterns from those more commonly used by some speakers can cause some difficulty in understanding words or speech fragments, LippinGreen (1997, p. 50), supported by the work of sociolinguists, concludes that "accent has little to do with communicative competence or the ability to use and interpret language in a wide variety of contexts effectively." 


\subsection{Research on non-native English speaker teachers' self-perceptions}

The critical perspective on nativespeakerism, with its far-reaching negative implications and effects, has encouraged the development of a robust body of research on NNESTs. To a great extent, this research agenda has focused on probing the bias of the "native speaker fallacy." Mahboob (2010) posits that this bias privileges native speaker norms and stereotypes NNESTs as imperfect users of the language. He advocates for new paradigms based on a functional view of language, which essentializes a speaker's skill in using language in real contexts; therefore, more valid, objective criteria, namely experience and education, to judge NNESTS' teaching ability are adopted.

Examining teachers' self-perception as regards their being or not being native speakers of the language, what they teach is undoubtedly a trend in the field. Findings in Reyes and Medgyes' study revealed that most of the participants identify themselves as non-native speakers (NNSs) of English. The majority, 68\%, considered that native and NNSTs' performances differ. This was corroborated by Samimy and Brutt-Griffler (1999), who also revealed that their participants did not favor any of the two categories of teachers as better than the other.

Subsequent studies by Llurda and Huguet (2003) and Butler (2007) contradicted these findings. Primary school teachers in their examinations believed that native English speaker teachers (NESTs) were better than NNESTs. The latter study exhibits a correlation between primary NNESTs' perception of themselves as having limited language competence and their adherence to the native speaker fallacy. Nonetheless, in Llurdas and Huguet's study, secondary school teachers had more confidence in their language skills and suggested that the native speaker was not necessarily the ideal in the profession.

Reyes and Medgyes' (1994) study determined that most NNESTs participants acknowledge that they faced limitations with regard to their knowledge and skills related to vocabulary, speaking, pronunciation, and listening. In addition, they thought those limitations did not have negative effects on their performance. Samimy and Brutt-Griffler's (1999) participants did not mention the use of the language to characterize themselves in relation to NESTs, but they did portray NESTs as fluent, accurate, and communicative-based users of the language. This perception of NESTs seem to relate to NNES teacher educators in findings from 
Dogancay-Aktuna (as cited in LLURDA, 2008) who considered their colloquial and conversational knowledge and skills as needing further development. Other studies such as Butler's (2007) found that participants self-perceived themselves as being stronger in their reading and writing competences than in their speaking ability. Similarly in Llurdas and Huguet's study, elementary school teachers considered their reading ability and grammar knowledge favorably.

NNESTs in Samimy and Brutt-Griffler's (1999) also believed that NESTs used a wide variety of teaching strategies and provided encouraging feedback to students. NNESTs were described as employing their L1 more in teaching, paying more attention to psychological and emotional factors, being more book and test oriented in their teaching, and having more knowledge in regards to who their students were. Akin to the last finding, Dogancay-Aktuna (as cited in LLURDA, 2008) determined that respondents felt their comprehension of contextual issues was higher because they were NNESTs instructors in an EFL setting.

Research has identified self-confidence issues in NNESTs' perception of themselves. NNESTs' self-perception as lacking the language ability that NESTs have (KIM's, 2011) or their permanent acknowledgement of their language difficulties could lead them to a negative self-perception with a related decline in language ability and an impression of inferiority (Reyes and Medgyes, 1994). In Bernat's (2008) research, NNESTs lacked experience and had language difficulties which generated a feeling of inferiority when compared to NESTs. Rajagopalan (2005) found that a group of NNESTs in Brazil thought they were not fully prepared to do their job, underestimated as teachers, limited in their options to grow, and were pursuing an unreachable ideal. Furthermore, their contact with native speakers triggered their anxiety. This study pointed out an interesting correlation: less experienced participants exhibited less concern regarding their lack of native speakership credentials.

\section{Research methodology}

Though the dominant research paradigm throughout the study was qualitative (PATTON, 2002; GLESNE, 2006; MILES, HUBBERMAN, and SALDAÑA, 2014), this article also employed quantitative techniques, namely descriptive statistics. In this sense, the study employed mixedmethods research (CRESWELL and PLANO, 2010). The study adopted 
a holistic perspective to look at participants by considering the natural settings where they usually live and the array of complex factors influencing their ratiocinations. Participants' perspectives became the driving force to work with the data, identify patterns in their self-perceptions, and build interpretations to answer the research questions.

\subsection{Context of the study}

In theory, Colombia is a multilingual country with $98 \%$ of the population speaking Spanish (GARCÍA and GARCÍA, 2012) and the remaining $2 \%$ speaking a myriad of indigenous languages as their first language. However, in practical terms, the majority of the country is monolingual (ORDONEEZ, 2011). Over the course of Colombia's history, English and its speakers have steadily elevated their status in the country, aligning with a world tendency to consolidate English as the global language (VELEZ-RENDÓN, 2003; DE MEJIA, 2005; GONZÁLEZ, 2010; USMA, 2009).

Though American English has traditionally enjoyed the highest prestige in the country, British English is the second most popular variety (GONZÁLEZ, 2010). In addition, as González, (2010, p. 337) remarks, "there seems to be little knowledge about outer circle varieties of English, which are commonly believed to be of lower prestige and linguistically impure." These preferences are related to the influence of the U.S. culture promoted through mass media and the current economic and political role the U.S. plays in the world. The British Council markets the use of British English through their perpetual and focused involvement in Colombia's foreign language educational policy and planning.

Several English teacher job ads, found on the internet, evidenced the high status of native speakers in the country through their limited education requirements (VELEZ-RONDÓN, 2003; GONZÁLEZ, 2010). They are usually preferred over national non-native teachers who may have more education than their native speaker counterparts. The following assertion by Velez-Rondón (2003, p. 197) summarizes the general social tendency in the country: "to rely on models imported from abroad that emphasize conformity to the standard and norms of an idealized English native speaker as the ultimate goal of language competence." 


\subsection{Setting and participants}

This study's participants and setting consist of two groups of students from two public universities. The first site was the Modern Languages program at University A in a small Colombian city of 145,000 inhabitants, characterized by a semirural environment in one of the neighboring "Departamentos" (states) to the capital city, Bogotá. University A offers a five-year- B.A. in education (EFL and Spanish as a mother tongue). Every year, the program welcomes two or three teacher assistants who support English classes. Usually they are U.S., England, or Jamaican born and work with non-native instructors in their classes. Table 1 summarizes the participants' main characteristics.

Table 1: University A Participants' characterization.

\begin{tabular}{|c|c|}
\hline Aspects & Description \\
\hline Number & 21 student-teachers (STs). \\
\hline Gender & 13 women $\& 8$ men. \\
\hline Age & $\begin{array}{l}\text { Range: } 18 \text { to } 28 \text { years of age. } \\
15 \text { STs: } 18 \text { to } 21 \text { \& 6A STs: } 22 \text { to } 28 \text { years of age. }\end{array}$ \\
\hline Origin & $\begin{array}{l}17 \text { STs: born in the city in which University A was located } \\
\text { or the surrounding small towns. } \\
4 \text { STs: from small towns in neighboring "Departamentos" } \\
\text { (states). }\end{array}$ \\
\hline $\begin{array}{l}\text { Background } \\
\text { Education(English) }\end{array}$ & $\begin{array}{l}12 \text { STs: started to learn English in primary school. } \\
2 \text { STs: began in pre-school. } \\
8 \text { STs: began by secondary school. } \\
5 \text { STs: had taken additional English courses prior to their } \\
\text { University teacher education program enrollment. }\end{array}$ \\
\hline $\begin{array}{l}\text { Year \& } \\
\text { University Course }\end{array}$ & $\begin{array}{l}\text { 3rd-year of studies. } \\
\text { Intermediate English I. }\end{array}$ \\
\hline Traveling & None of them had traveled to an English speaking country. \\
\hline $\begin{array}{l}\text { Contact with Native } \\
\text { Speakers }\end{array}$ & $\begin{array}{l}16 \text { STs: had been in contact with native speakers. } \\
11 \text { STs (out of the previous 16) had contact with University } \\
\text { Native Speaker Assistants. }\end{array}$ \\
\hline
\end{tabular}


The second site was the Foreign Languages program at University B in Bogotá. Bogotá, a megalopolis, is the capital of Colombia with approximately 7 million inhabitants. University B, offers a 4-year B.A. in education (EFL), in which the course of study is concentrated in only one language, English. Two teacher's assistants, generally from the U.S. or England, spend a year in the program supporting non-native instructors' lessons. Table 1 summarizes participants' main characteristics.

Table 2: University B participants' characterization.

\begin{tabular}{|c|c|}
\hline Aspects & Description \\
\hline Number & 20 student-teachers (STs). \\
\hline Gender & 12 women $\& 8$ men. \\
\hline Age & $\begin{array}{l}\text { Range: } 16 \text { to } 29 \text { years of age. } \\
\text { 16 STs: } 17 \text { to } 20 \& 4 \text { STs: } 21 \text { to } 29 \text { years of age. }\end{array}$ \\
\hline Origin & $\begin{array}{l}14 \text { STs: born in the city in which University B was located. } \\
6 \text { STs: born in other major cities in the country. }\end{array}$ \\
\hline $\begin{array}{l}\text { Background } \\
\text { Education (English) }\end{array}$ & $\begin{array}{l}\text { 12: started to learn English in primary school. } \\
\text { 5: began in pre-school. } \\
\text { 3: began in secondary school. } \\
\text { 5: had taken additional English courses prior to their program } \\
\text { enrollment }\end{array}$ \\
\hline Year \& University Course & $\begin{array}{l}2^{\text {nd }} \text { year of studies. } \\
\text { Oral Communication III. }\end{array}$ \\
\hline Traveling & 1 of them had traveled to an English speaking country. \\
\hline $\begin{array}{l}\text { Contact with Native } \\
\text { Speakers }\end{array}$ & $\begin{array}{l}\text { 16: had been in contact with native speakers. } \\
\text { 11: out of these, } 16 \text { had contact with University Native } \\
\text { Speaker Assistants. }\end{array}$ \\
\hline
\end{tabular}

\subsection{Data collection and analysis}

The first data collection instrument was a survey. Forty three questions elicited information regarding participants' background and self-perceptions as future (non) native speaker EFL teachers (Appendix 1 includes a sample of the type of questions used in this survey). The instrument combined closed and open questions, which were taken and/or adapted from existing instruments (MEDGYES, 1999; RAJAGOPALAN, 2005; LLURDA, 2008) to ensure their validity. By means of a software online application, all participants (41) provided their answers to the questions in the instrument. 
Phenomenological (SEIDMAN, 2006) semi-structured (LEECH, 2002; MERRIAM, 2009) one-hour-online interviews became the second tool to gather information. An online application was used to record participants' responses. This instrument helped to expand upon participants' answers in questionnaires. Nine students from University A and nine from University B participated in the interview via Skype. In addition, the curriculum of the two programs, the syllabi of courses in which students participated, and the program's web-pages served as information sources.

Descriptive statistics, namely percentages, were employed to study the quantitative data (DÖRNYEI, 2003). Data analysis software contributed to the organization, examination, systematization of coding, and visualization of qualitative data. The analysis of this type of data encompassed the description of participants' self-perceptions and the study of data interrelations to identify patterns in the information. By constant comparison and reduction of data, similar patterns were grouped to form categories and sub-categories (MARSHALL and ROSSMAN, 2011; MERRIAM, 2009). Testing and verification of data in multiple revisions of initial categories and subcategories by crossing emerging patterns with one another led to the final version of findings included in this manuscript.

\section{Findings}

Data analysis suggested that, as prospective NNESTs, participants exhibited two interrelated images of themselves. On the one hand, they viewed NNESTs as lacking the ability to attain the level of language expertise and cultural knowledge that they believe NESTs possess. This first image constitutes a perpetuation of their self-perceptions concerning their being non-native speakers of English. On the other hand, they saw themselves as prospective teachers who possess advantageous conditions associated with their non-native speaker status and with the capacity to acquire the necessary preparation to succeed in their future jobs.

\section{1 "NNESTs can have a very good language mastery, but that's not the ideal"}

Participants' self-perceptions were substantially affected by their view of themselves as exhibiting a partial mastery of the language. When answering survey questions, prospective-teachers repeatedly mentioned they 
were lacking knowledge and skills necessary to achieve their envisaged goals in the use of English. For some, these goals gravitated primarily towards their acquiring sufficient skills to be able to maintain communications with other English speakers (13 University A and 8 University B prospective teachers), whereas for others the aim was to achieve native-like proficiency and mimic a native speaker's communicative performance (8 University A and 15 University $B$ prospective teachers).

The following excerpt, for instance, illustrates this prospective English teacher's perception that his English oral ability was not good enough. Though the participant did not provide a description of his skills to show serious limitations, he expressed his concern about not having achieved what he regarded as the "ideal standard": "Sometimes I listen to myself speaking, and I feel like I'm missing something, like a bit of fluency to achieve the right accent" (UniA-S2-INT-February 21, 2014) ${ }^{2}$. Another participant expressed: "The idea of speaking another language (second/foreign) is to do it very much akin to the way a native speaker does it" (UniA-S5-Q-February 22, 2014).

Regarding language proficiency, participants considered NNESTs to be at a disadvantage when compared to NESTs. Table three below shows that forty $40 \%$ of University B pre-service teachers identify various aspects of language abilities (spoken language $25 \%$ and fluency $15 \%$, added together), as what NNESTs were missing as regards support for their students. Language ability was only surpassed by the lack of cultural knowledge at $45 \%$. Similarly $25 \%$ of University A participants ranked language abilities second to cultural knowledge at $43 \%$. In addition, participants' answers regarding who they would advise to become a relative's English teacher favored NESTs over NNESTs. Table four indicates that $62 \%$ of University $A$ and $55 \%$ of University B pre-service teachers would recommend a Native Speaker, while $33 \%$ of University A and $40 \%$ of University B would recommend NNESTs.

\footnotetext{
${ }^{2}$ Throughout this article, abbreviations are used to identify quoted answers from participants": "UniA" and "UniB" refer to the university where they studied. "S" followed by a number is used to identify students. As for the instruments from which a piece of evidence was taken, Q. stands for questionnaire and INT. for interview. The author of the article includes his translation of participants' original testimonies, which were provided in Spanish, keeping faithful to participants' original ideas.
} 
Table 3: Participants' opinions regarding what NNESTs offer and are missing.

\begin{tabular}{|l|c|c|c|c|}
\hline \multirow{2}{*}{ TS' Qualifications } & \multicolumn{2}{|c|}{ University A } & \multicolumn{2}{c|}{ University B } \\
\cline { 2 - 5 } & $\begin{array}{c}\text { N N E S Ts } \\
\text { can offer }\end{array}$ & $\begin{array}{c}\text { N NES Ts } \\
\text { miss }\end{array}$ & $\begin{array}{c}\text { N N E S Ts } \\
\text { can offer }\end{array}$ & $\begin{array}{c}\text { N NES Ts } \\
\text { miss }\end{array}$ \\
\hline $\begin{array}{l}\text { More help to understand \& } \\
\text { adapt to L2 \& C2 }\end{array}$ & $38 \%$ & & $35 \%$ & \\
\hline $\begin{array}{l}\text { More techniques to address } \\
\text { learning difficulties }\end{array}$ & $14 \%$ & & & \\
\hline $\begin{array}{l}\text { More Knowledge of learning } \\
\text { strategies for L2 learning }\end{array}$ & $14 \%$ & & $35 \%$ & \\
\hline A good model & $5 \%$ & & $15 \%$ & \\
\hline $\begin{array}{l}\text { Higher awareness of Ss } \\
\text { sociocultural background }\end{array}$ & $10 \%$ & & & \\
\hline Others & $23 \%$ & & $15 \%$ & \\
\hline $\begin{array}{l}\text { More accuracy in spoken } \\
\text { language }\end{array}$ & & $10 \%$ & & $25 \%$ \\
\hline $\begin{array}{l}\text { More accuracy in written } \\
\text { language }\end{array}$ & & $5 \%$ & & $15 \%$ \\
\hline Fluency & & $10 \%$ & & $45 \%$ \\
\hline $\begin{array}{l}\text { A better knowledge of L2 } \\
\text { associated cultures }\end{array}$ & & $32 \%$ & & $15 \%$ \\
\hline Others & & & \\
\hline
\end{tabular}

Table 4: Participants' advice about hiring someone as an English teacher.

\begin{tabular}{|l|c|c|}
\hline Teachers' Qualifications & U A & U B \\
\hline A native speaker from another country who could speak Spanish & $5 \%$ & $5 \%$ \\
\hline An English native speaker who could speak Spanish & $62 \%$ & $45 \%$ \\
\hline A non-native English speaker from Colombia & $33 \%$ & $40 \%$ \\
\hline An English native speaker who could not speak Spanish & & $10 \%$ \\
\hline
\end{tabular}

Moreover, 10 University A and 11 University B prospective teachers explained in surveys and interviews that it was possible for NNESTs to achieve proficiency in the use of the language. Nonetheless, they considered it impossible to become the ideal - the native speaker. NNESTs were 
considered better prepared to explain the grammatical structure of the language, including its formal and basic aspects, and as such were more suitable to teach initial instructional levels. Conversely NESTs were more qualified to teach advanced levels. As an example of these opinions, one participant expressed:

The non-native speaker teacher's weakness is that he/she can master the language but he/she cannot do it a 100\%, I mean he/she can be close to having a very good mastery of the language, but that's not the ideal any way (INT-S7-UniB-February 27, 2014).

Participants recalled that several of their primary and secondary school teachers did not exhibit what they consider acceptable oral skills. They expressed concerns that what they perceived as prospective NNESTs' limitations could be transmitted from their primary and secondary school teachers through them to their future students. One of them commented:

Non-native people acquire, we could call them "bad habits" or they pronounce words inappropriately, and then they teach that to their students, this means that students acquire these "bad habits", so they do not teach the right way to pronounce words... (INT-S9-UniB-February, $28,2014)$.

As findings reported in the next section will show, the majority of participants perceived that there were advantages and opportunities that became avenues to build themselves as competent NNESTs in the future. However, a few of them, 2 University A prospective teachers, feared that they might not be hired if they had to compete with a native speaker, and 1 University A prospective teacher thought she could be a victim of harassment from her students if she did not exhibit a native-like English.

\section{2 "It is good to give NESTS and NNESTS a chance to teach so long as they are prepared"}

When thinking about their future performance as teachers, most participants in both universities, $67 \%$ of University A participants and 75\% of University B, did not show concerns about not being regarded as a NEST. Another survey question, asking participants who they would hire to work in a language institute, showed that in both universities, $90 \%$ of University B and $81 \%$ of University A prospective teachers, would hire an even number of 
NNESTs and NESTs (See Table 5). In this vein, they do not see themselves in a disadvantageous position in comparison with NESTs. In fact, while $57 \%$ of University A students think NNESTs are more successful than NESTs, $43 \%$ think the opposite. Similarly, $83 \%$ of University B students believe that NNESTs are more successful than their counterparts.

Table 5: Participants' views on who they would hire to work in a language institute.

\begin{tabular}{|l|c|c|}
\hline Participants' opinion regarding who they would hire & UniA & UniB \\
\hline More native speakers than non-native speakers & $5 \%$ & $5 \%$ \\
\hline The same number of native speakers as non-native speakers & $81 \%$ & $90 \%$ \\
\hline More non-native speakers than native speakers & $14 \%$ & $5 \%$ \\
\hline
\end{tabular}

The role models that participants identify for their future teaching jobs attest to their overarching perception of themselves as having a significant chance of becoming competent English teachers despite their self-perceived non-nativeness. Through data from interviews, it was found that all prospective teachers (18) who were interviewed designated a Colombian NNEST as their role model. Despite the fact that most of them had not been taught by NESTs, only two of those pre-service teachers who were interviewed had ever had NESTs; the reasons they put forward to explain their preference for NNESTs as role models corroborate their positive opinion regarding these educators, as stated in the surveys.

Their NNEST role models were admired because they spoke clearly in English, thus facilitating students' understanding. A couple of students commented that they preferred teachers who did not try to imitate native speakers' accents, since that imitation might complicate their comprehension. Moreover, they appreciated teachers who excelled in their use of engaging methodologies, which again made it easier to understand topics. Finally, a positive encouraging attitude towards students' learning process, being kind but demanding, and facilitating a cordial relationship with students, constituted pivotal characteristics of the role models they chose. On the whole, prospective teachers highlighted qualities in their role models that confirm their view of NNESTs as potentially competent since they promote suitable learning environments and implement successful pedagogical frameworks. Related findings are presented below: 
I like how he (his role model) socialized with students, he liked the music that I liked and we talked and he got you involved in reading. He really filled you with knowledge and if you made mistakes he was not telling you 'this is wrong' (he uses a scolding voice)...He would say, 'let's see the positive side of this' and that's how you learn, when you're corrected little by little (UniA-S14-INT-February 23, 2014).

The first of two dimensions to explain pre-service teachers' selfcharacterization as competent prospective teachers involves their belief that their experience learning English in Colombia has equipped them with knowledge to buttress their future students' language education. In this regard, 38\% of University A and 35\% of University B pre-service teachers answered in the survey that NNESTs' were particularly skilled at helping their students understand and adapt to the foreign language. Five percent of University A and 15\% of University B pre-service teachers considered NNESTs to be "good models" to follow and 10\% of University A students highlighted "their awareness of their students' sociocultural background" (See Table 3).

Qualitative data from surveys and interviews revealed that 14 University B and 12 University A students underscored NNESTs' language learning background as a key element of their future job performance. Participants believed that NNESTs are acutely aware and understand their students' difficulties and needs. Moreover, they are skilled at identifying factors affecting the teaching-learning process. NNESTs' experiences as learners inform their pedagogical judgment, which in turn leads to sound choices when adapting, adopting, or creating curricular elements. The next excerpt exemplifies the previous perspective:

I feel much more comfortable with a NNEST, I am talking about myself, I am a student and I feel more comfortable, more confident because you know you are talking about the same things, you know you have lived and share the same culture, the same context (UniA-S10-INT-February $22,2014)$.

Regarding the second dimension of their self-perception as competent prospective non-native teachers, several participants thought that their education would grant them the required qualifications to teach. In general, those students who showed the least concern explained that, by the end of their undergraduate program, their language limitations would probably be reduced because of their studies. 
Data from interviews provided by six University B and five University A pre-service teachers revealed that, despite their perception of NNESTs as not being the ideal in terms of their language ability, participants believed that NNESTs could succeed in their teaching jobs. Education was regarded by several participants as the most relevant criteria used to judge how qualified a teacher was. Not only undergraduate education but also continuous education after graduation would make a NNEST competent. In this regard, a participant commented:

I think that what I am studying in the university will help me to learn about the tools I need to be a good teacher... so I don't think my teaching will be deficient, I don't know, I don't think that not being a native speaker will be a barrier (UniB-S9-INT-February 28, 2014).

\section{Discussion}

This study results agree with various other studies in which NNESTs believed that they lacked the ability to attain NESTs' idealized language expertise and cultural knowledge. For instance, Bernat (2008) determined that her participants, some of whom were prospective teachers, partially define NNESTs' identity on the grounds of their language problems. As regards overall language ability, in Samimy and Brutt-Griffler (1999), Árva and Medgyes (2000), and Norton and Tang's (1997) studies, NESTs' were considered more competent than NNESTs. More specifically, Colombian pre-service teachers pointed mainly to oral language abilities as the most concerning aspect in NNESTs' profiles, corroborating findings in im ek (2012), Reyes and Medgyes (1994), and Dogancay-Aktun's (as cited in LLURDA, 2008) studies.

The Colombian participants' views depicting NNESTs' knowledge of the English language culture as limited was shared by NNESTs' in findings from Moussu (2006) and Reyes and Medgyes (1994). Those same Colombian participants, however, perceived NNESTs to be more skillful in writing, reading, and grammar, which aligns with conclusions presented in studies from Llurda and Huguet (2003) and Butler (2007).

Considering participants' concerns about their language ability, the myth of the native speaker translates into the native speaker fallacy. This concurs with that reported by Llurda (2009, p. 41): "The native teacher as the ideal teacher was equivalent to the monolingual native speaker as the 
ideal speaker." The axiomatic power of the native speaker fallacy influences NNESTs as much as prospective teachers in this study who transfer their ideologically charged self-perceptions from their role as learners to their prospective role as teachers.

As a result of their self-perceived insufficient skills as speakers of English, twelve University A and nine University B pre-service teachers experienced frustration, felt a lack of confidence, and were afraid to engage in interactions, especially with native speakers. Interestingly, when sharing their self-perceptions concerning their future as English teachers, only two University A and one University B pre-service teachers reported these affective states. Possible explanations for this decrease in concern might be related to prospective teachers' confidence in their future, as explained in the upcoming pages, and their distance from possible job-related prejudice based on their lack of teaching experience.

The three prospective teachers mentioned above felt anxious about the prospect of being denied job opportunities if their language competence was not judged to be native-like or about being subjected to aggravation from their students for the same reason. Anxiety in NNESTs due to a lack of language ability, leading to feelings of inferiority, has been widely reported in prior studies (KIM, 2011; REYES AND MEDGYES, 1994; BERNAT, 2008; RAJAGOPALAN, 2005).

Though only a small number of Colombian prospective teachers who participated in this study, who were in their second and third year of studies, and who had not even enrolled in teaching practicum experiences, reported anxiety-related issues. Their testimonies underscore the impact of perceived future prejudice on their self-perceptions. In this vein, reviewing the history of the field, Llurda (2009) remarks that the discrimination that NNESTs suffer has often been seen as a pivotal factor in the development of their professional self-esteem.

Even though participants' unfavorable self-perception of their language abilities in comparison to native speakers revealed their adherence to the native speaker fallacy, other aspects of their self-perception challenged this ideology. They believed that as prospective NNESTs they possessed meaningful and distinct culture-bound experiential knowledge that they could use in their teaching. By the same token, they considered that NNESTs were more knowledgeable about their students socio-cultural context, which concurs with findings in studies conducted by Dogancay-Aktuna (as cited 
in LLURDA, 2008), Samimy and Brutt-Griffler (1999), Árva and Medgyes (2000), among others. In a similar manner, participants' reports in im ek (2012), Inbar-Lourie, (2005), and Árva and Medgyes (2000) were similar to those of Colombian prospective teachers' remarks about NNESTs' ability to facilitate their students' English language comprehension. They considered that NNESTs speak clearly, can use L1 as a communication strategy, and employ supporting methodologies.

Furthermore, pre-service teachers regarded NNESTs as able to understand students' needs and difficulties, which encourages their adaptation to the language. This finding has also been reported by Norton and Tang, (1997), Árva and Medgyes (2000), Dogancay-Aktuna (as cited in LLURDA, 2008), and im ek (2012). Pre-service teachers characterized NNESTs as exhibiting a helpful attitude that motivates them to continue learning and as being models for students, which is supported by Moussu's (2006) research. The previous positive views that participants held regarding NNESTs' teaching roles match Kamhi-Stein's (2005) discussion about the change in the NNEST's classroom role from initially being deemed problematic and undesirable to more recently being regarded as an asset. This author explains, citing Seidlhofer (1999), that possessing knowledge of the two cultures and languages allows NNESTs to mediate between them, which is beneficial to students.

Another participants' view, which confronts the native speaker fallacy partially engrained in participants' self-perceptions of themselves, emanates from their confidence in their future teaching performance. Similarly, Bernat (2008, p. 6) reported, regarding her participants, that they "at times felt overwhelmed by what they were undertaking in their career, [but] they also saw a possibility of success." In the particular case of the target student teacher population, findings indicate that their ongoing preparation process contributes to their confidence in their prospective achievements and their construction of positive self-images, despite pervasive nativespeakersism ideologies. Colombian pre-service teachers perceived that their education during their undergraduate program and throughout their career will help them fight possible prejudice:

Well, I believe that you are always concerned (about not being a NEST), but you study your program and well, I imagine that later on you will enroll in specialization programs, yes, then, at the end, people prejudice, I mean, I think if I studied a university program to get professional 
preparation to be an English teacher, why should I have to worry about others looking at me as a NNEST? (UniB-S2-INT-March 2, 2014).

These findings align with a vast number of scholars' views that the criteria to judge NNESTs' teaching performance should not be based on nativespeakership credentials, but rather on overall qualification and experience (RAMPTOM, 1990; LLURDA, 2009; MAHBOOB, 2010). Both NNESTs and NESTs can fulfill those conditions through education and practice.

Overall Colombian prospective teachers rejected the native speaker fallacy. This tendency to disregard their non-native speaker status when pondering their future teaching career might be related to findings in Rajagopalan's (2005, p. 209) study: “...those [his participants] with less teaching experience (and presumably from a younger generation) were less worried about their being non-natives than those who have been in the profession for upwards of 10 years."

Despite this clear tendency in the majority of participants' responses to challenge the overarching assumption behind the native speaker fallacy, when asked whom they would suggest others to hire as an English teacher, $62 \%$ of University A and $55 \%$ of University B pre-service teachers chose NESTs. This finding makes the prevalent ambivalence in participants' perceptions apparent. NNESTs can be successful in their jobs, but they do not possess the ideal language ability that native NESTs do. Though they are undergraduate prospective teachers who have never had a teaching job, their conflicting views seem to echo Llurda's (2009). Llurda posits that, although NNESTs are affected by the ideology of discrimination, which favors native speakers, they uphold the ideology favoring native speakers. It seems that, regarding language ability, even before their debut as teachers, participants' self-images have been affected by ideologies that encourage a view of themselves as inferior to NESTs.

\section{Conclusions and implications}

Findings in this study show that participants' self-perceptions fully intersected with the myth of the native speaker and partially with the native speaker fallacy. Their self-perceptions as English speakers affected their views as future teachers. Student teachers feared the disadvantages that no achieving native-like abilities could bring into their lives and 
future profession. Being the target of future social sanctions, if regarded as incompetent or "too Spanish-like", constituted an important element in their self-images.

However, their self- perceptions were also imbued with confidence concerning their future. Because they viewed themselves as part of a teacher education program, they relied on their education process to achieve not only their language goals, but also to equip themselves with pedagogical tools. Finally, when participants expanded their views of what teaching English encompassed: their accumulated experience as learners, the shared knowledge of the sociocultural context with future students, and their potential to become a bridge between English and Spanish cultures and languages, led them to feel empowered to succeed in their future jobs.

In Colombia, the analysis of nativespeakerism and associated ideologies, and of their effect on NNESTs' lives and careers, has been practically non-existent. This study seeks to fill that gap. Scholars, working in the field of NNESTs, have concentrated on graduate pre-service teachers in outer and inner circle nations. That specificity of most available research should be considered a caveat for the suggestions presented in this section.

A focus on prospective teachers' self-perceptions has allowed this study to expose their rationalizations regarding language and its teaching as intertwined with subjectivity categories, namely affect, personality, identity, and motivation. These are issues that have slowly started to be taken into consideration as part of the conceptualization and agenda of teacher education programs. Emerging experiences in other countries can be considered instances proposed as contextualized alternatives. Consequently, Colombian scholars can learn from international initiatives, but local programs need to suit the characteristics of Colombian pre-service teachers in specific regions. That having been said, Wu, Liang, and Csepelyi (2010, p. 205) propose an interesting example of strategies integrated in teacher education courses. The strategies address subjectivity issues in teachers' lives and careers since they "aim at helping NNESTs combat negative emotions, such as fear, anxiety, lack of self-worth, and any sense of isolation, through restructuring their self-efficacy beliefs and redefining their self-identity as professional language educators."

Due to the ubiquity of nativespeakerism ideologies across university curricula, this study concurs with scholars in fields as EIL, ELF, and WEs who warn us about the need to revise our traditional commitment to EFL 
and ESL as overarching approaches to English learning and teaching, especially in expanding circle nations like Colombia. In this vein, Kachru and Nelson (1996, p. 79), within the WEs framework, posit that:

The concept of English in its Inner, Outer and Expanding Circles is only superficially equivalent to native, ESL and EFL. In thinking of a country as an ESL country [or EFL for that matter] or of a person as an ESL speaker, for example, we perpetuate the dichotomy of native versus non-native, 'us versus them.'

EIL, ELF, and WEs become examples for teacher educators, teachers, and pre-service teachers, so that they can explore alternatives to the current EFL conceptualization undergirding pedagogical practices. The EFL perspective based on the premise that individuals in countries, such as Colombia, learn English mainly to interact with native speakers is currently inadequate, since, as Kramsch and Sullivan (1996, p. 211) put it, "appropriate pedagogy should prepare learners to be both global and local speakers of English and to feel at home in both international and national cultures."

The critical analysis of nativespeakerism ideologies in the ELT curriculum conducted by various scholars can buttress the development of awareness regarding these myths and the design of favorable pedagogical proposals. Analysis has targeted influential teaching approaches as Communicative Language Teaching (ALPTEKIN, 2002; MCKAY, 2002), the formulation of learning objectives (COOK, 2007), and the materials selected for teaching (ZIAEI, 2002; BALEGHIZADEH AND MOTAHED, 2010).

Due to the pervasive power of nativespeakerism ideologies, a crucial task that educators face is to enhance their students' development of what Modiano (2010, p. 165) calls ideological literacy: “[...] to demonstrate awareness of the cultural beliefs and values underpinning the speech communities which are presumed to be in possession of the prestige varieties [...]" In order to trigger language awareness and eventually guide students and teachers in the development of ideological competence, strategies rooted in diverse approaches, such as critical discourse analysis, critical pedagogy, critical applied linguistics, and critical language awareness, can be employed in teacher education programs, undergraduate programs, or even at the school level with English learners.

The aforementioned approaches can promote strategies which employ pedagogical sources that value the potential, diverse, and changing linguistic 
and course participants' cultural profiles. Additionally, these strategies are expected to encourage teachers and learners not only to become mediators in culturally and linguistically diverse pedagogical settings (and hopefully in their lives outside the classroom), but also to contest the discriminatory attitudes grounded in (non) nativeness ideologies.

\section{References}

ALPTEKIN, C. Towards intercultural communicative competence. ELT journal, v. 56, n.1, p. 57-64, 2002.

ÁRVA, V.; MEDGYES, P. Native and non-native teachers in the classroom. System, v. 28, n.3, p. 355-372, 2000.

BALEGHIZADEH, S., ; MOTAHED, M. J. An analysis of the ideological content of internationally-developed British and American ELT textbooks. The Journal of Teaching Language Skills, v. 2, n.2, p. 1-27, 2010.

BELZ, J. A. The myth of the deficient communicator. Language Teaching Research, v. 6, n.1, p.59-82, 2002.

BERNAT, E. Towards a pedagogy of empowerment: the case of "impostor syndrome" among pre-service non-native speaker teachers in TESOL. English Language Teacher Education and Development, v. 11, p. 1-8, 2008.

BRAINE, G. A history of research on non-native speaker English teachers. In: Brain, G. (Ed.). Non-Native language teachers. Springer US, 2005. p. 13-23.

BRUTT GRIFFLER, J. ; SAMIMY, K. K. Transcending the nativeness paradigm. World Englishes, v. 20, n.1, p. 99-106, 2001.

BUTLER, Y. G. How Are Non-native English Speaking Teachers Perceived by Young Learners? Tesol Quarterly, v, 41, n. 4, p. 731-755, 2007.

CANAGARAJAH, A. S. Interrogating the "native speaker fallacy": Non-linguistic roots, no-pedagogical results. In: Blyth, C. (Ed.). The sociolinguistics of foreignlanguage classrooms: contributions of the native, the near-native, and the nonnative speaker. Issues in language program direction. Boston: Heinle, 1999. p.77-920.

COOK, V. Going beyond the native speaker in language teaching. TESOL quarterly, v. 33, n.2, p. 185-209, 1999.

COOK, V. The Goals of ELT. In: CUMMINS, J.; DAVISON, C. International handbook of English language teaching. Springer US, 2007. p. 237-248.

CRESWELL, J. ; PLANO, V. Designing and conducting mixed methods research. Thousand Oaks: Sage, 2010. 
DAVIES, A. The native speaker in applied linguistics. In: Davis, A.; Elder, C. (Eds.). The handbook of applied linguistics. Oxford: Blackwell, 2004, p. 431-450.

DE MEJÍA, A. M. Bilingual education in Colombia: Towards an integrated perspective. International Journal of Bilingual Education and Bilingualism, v. 7 , n. 5, p. 381-397, 2005.

DÖRNYEI, Z. Questionnaires in second language research. New Jersey: Lawrence Erlbaum Associates, 2003.

FIRTH, A., ; WAGNER, J. On discourse, communication, and (some) fundamental concepts in SLA research. The modern language journal. v.81, n. 3, p. 285-300, 1997.

GARCÍA LEÓN, J., ; GARCÍA LEÓN, D. Políticas lingüísticas en Colombia: tensiones entre políticas para lenguas mayoritarias y lenguas minoritarias. Boletín de filología, v. 47, n.2, p. 47-70, 2012.

GLESNE, C. Becoming qualitative researchers. Boston: Pearson, 2006.

GONZÁLEZ, A. English and English teaching in Colombia. In: KIRKPATRICK, A. The Routledge Handbook of World Englishes, 2010, p.332.

GRADDOL, D. The decline of the native speaker. In: Anderman, G.; Rogers, M. (Eds.). Translation today: trends and perspectives. Clevedon: Multilingual Matters, 2003, p.152-167.

GUERRERO, C.H. Bilingual Colombia: What does it mean to be bilingual within the framework of the National Plan of Bilingualism? Profile, v. 9, p. 27-45, 2008. HOLLIDAY, A. Native-speakerism. ELT journal, v. 60, n. 4, p. 385-387, 2006.

INBAR-LOURIE, O. Mind the gap: Self and perceived native speaker identities of EFL teachers. In: Llurada, E. (Ed.). Non-native language teachers. New York: Springer US, 2005, p. 265-281.

JENKINS, J. Current perspectives on teaching world Englishes and English as a lingua franca. Tesol Quarterly. v. 40, n. 1, p. 157-181, 2006.

KACHRU, B. The alchemy of English: The spread, functions, and models of non-native Englishes. University of Illinois Press, 1990.

KACHRU, B., ; NELSON, C. World Englishes. In: Mckay, S. L. ; Hornberger, N.H. Sociolinguistics and Language Teaching. Cambridge: CUP, 1996, p 71-102. KAMHI-STEIN, L. D. Research perspectives on non-native English-speaking educators. In: Bruthiaux, P.; Atkinson, D; Eggington, W; Grabe, W. ; Ramanathan, V. (Eds.). Directions in applied linguistics: Essays in honor of Robert B. Kaplan. Clevedon: Multilingual Matters, 2005, p. 72-83.

KIM, H. K. Native Speakerism Affecting Non-native English Teachers' Identity Formation: A Critical Perspective. English Teaching, v. 66, n.4, p.53-71, 2011. 
KRAMSCH, C. ; SULLIVAN, P. Appropriate pedagogy. ELT Journal, v. 50, n.3, p. 199-212, 1996.

KRAMSCH, C. \& LAM, W. S. Textual identities: The importance of being nonnative. In: Braine, G. (Ed.). Non-native educators in English language teaching. Mahwah: Lawrence Erlbaum Associates, 1999, p. 57-72.

KRAMSCH, C. The privilege of the non-native speaker. In: Blyth, C. (Ed.). The Sociolinguistics of Foreign-Language Classrooms: Contributions of the Native, the Near-native, and the Non-native Speaker. Boston: Heinle, 2003, p.251-262. LEECH, B. L. Asking questions: techniques for semi-structured interviews. Political Science and Politics, v. 35, n. 4, p. 665-668, 2002.

LIPPI-GREEN, R. English with an accent: Language, ideology, and discrimination in the United States. Psychology Press, 1997.

LLURDA, E. The effects of stays abroad on self-perceptions of non-native EFL teachers. In: Dogancay-Aktuna, S. ; Hardmann, J. (Eds.). Global English teaching and teacher education: Praxis and possibility. Alexandria: TESOL, 2008. p. 99111.

LLURDA, E. The Decline and fall of the native speaker. Contemporary Applied Linguistics, v. 1, p. 37-53, 2009.

LLURDA, E. ; A. HUGUET. Self-awareness in NNS EFL primary and secondary school teachers. Language Awareness, v. 13, p. 220-235, 2003.

MAHBOOB, A. Beyond the native speaker in TESOL. Culture, context, \& communication. p. 60-93, 2005.

MAHBOOB, A. The NNEST lens. New Castle: Cambridge Scholars Publishing, 2010.

MARSHALL, C.; ROSSMAN, G. Designing qualitative research. Thousand Oaks: Sage, 2011.

MCKAY, S. L. Teaching English as an international language: Rethinking goals and perspectives. NY: OUP, 2002.

MEDGYES, P. The non-native teacher. Germany: Hueber, 1999.

MERRIAM, S. B. Qualitative research: A guide to design and implementation. San Francisco: Jossey-Bass, 2009.

MILES, M., HUBERMAN, A. ; SALDAÑA, J. Qualitative data analysis: A methods sourcebook. SAGE Publications, Inc, 2014.

MODIANO, M. Ideology and the ELT practitioner. International Journal of Applied Linguistics, v.11, n.2, p. 159-173, 2001. 
MODIANO, M. Standard English (es) and educational practices for the world's lingua franca. English Today, v.15, n.4, p. 3-13,1999.

MOUSSU, L. Native and non-native English-speaking English as a second language teachers: Student attitudes, teacher self-perceptions, and intensive English program administrator beliefs and practices. (2006). (Unpublished doctoral dissertation)Purdue University, West Lafayette.

MOUSSU, L. ; LLURDA, E. Non-native English-speaking English language teachers: History and research. Language Teaching, v. 41, n.3, p.315-348, 2008. NORTON, B. ; TANG, C. The identity of the non-native ESL teacher on the power and status of non-native ESL teachers. Tesol Quarterly, v.31, n.3, p. 577580. 1997.

ORDONEEZ, C. L. Education for bilingualism in international languages in a monolingual Socio-Linguistic context. Lenguaje, v. 36, n.2, p. 353-384, 2011.

PAIKEDAY, T. The native speaker is dead!: An informal discussion of a linguistic myth with Noam Chomsky and other linguists, philosophers, psychologists, and lexicographers. Ontario: PPI, 1985.

PATTON, M. Q. Qualitative research and evaluation methods. Thousand Oaks: Thousand Oaks: Sage, 2002.

PENNYCOOK, A. The cultural politics of English as an international language. London: Longman, 1994.

PHILLIPSON, R. ELT: The native speaker's burden? ELT journal, v. 46. n.1, p. 12-18, 1992.

RAJAGOPALAN, K. Linguistics and the myth of nativity: Comments on the controversy over 'new/non-native Englishes'. Journal of Pragmatics, v. 27, n.2, p. 225-231, 1997.

RAJAGOPALAN, K. Non-native speaker teachers of English and their anxieties: Ingredients for an experiment in action research. In: Llurda, E. (Ed.) Non-Native language teachers: Perceptions, challenges and contributions to the profession. Springer US, 2005, p. 283-303.

RAMPTON, M. B. H. Displacing the 'native speaker': Expertise, affiliation, and inheritance. ELT journal, v. 44, n.2, p.97-101, 1990.

REYES, T. ; MEDGYES, P. The non-native English speaking EFL/ESL teacher's self-Image: An international survey. System, v.22, n.3, p. 353-367, 1994.

SAMIMY, K. ; J. BRUTT-GRIFFLER. To be a native or non-native speaker: Perceptions of 'non-native' students in a graduate TESOL program. In: Braine, G. (Ed.). Non-native educators in English Language Teaching. New Jersey: Lawrence Erlbaum Associates, 1999. p.127-144. 
SAYER, P. Demystifying language mixing: Spanglish in school. Journal of Latinos and Education, v. 7, n.2, p.94-112, 2008.

SEIDMAN, I. Interviewing as qualitative research: A guide for researchers in education and the social sciences. New York: Teachers college press, 2006.

IM EK, M. Evaluation of Student Teachers' opinions on The Native /Non-Native Dichotomy. Mustafa Kemal University Journal of Social Sciences Institute, v.9, n.17, p. 469-496, 2012.

TRAIN, R. "Real Spanish:" Historical Perspectives on the Ideological Construction of a foreign language. Critical Inquiry in Language Studies, ???, v.4, n. 2-3, p. 207-235, 2007.

TRAIN, R. Language ideology and foreign language pedagogy. In: Ayoun, D. (Ed.). French applied linguistics. Benjamins Publishing, 2011, p. 238-269.

USMA, J. Globalization and language and education reform in Colombia: A critical outlook. Íkala, v.14, n. 2, p.19-42, 2009).

VALENCIA, M. Language Policy and the Manufacturing of Consent for Foreign Intervention in Colombia. Profile. v.15, n.1, 2013.

VELEZ-RENDÓN, G. English in Colombia: A sociolinguistic profile. World Englishes. v.22, n. 2, p. 185-198, 2003.

VIAFARA, J. Self-perceived (non) nativeness and Colombian prospective English teachers in telecollaboration. (2015). (Unpublished doctoral dissertation). The University of Arizona.

WHITE, L. ; GENESEE, F. How native is near-native? The issue of ultimate attainment in adult second language acquisition. Second Language Research. v. 17, p. 233-265, 1996.

WU, A. ; LIANG, J. ; CSEPELYI, T. Coping strategies for NNESs teachers' Development. In Mahboob, A. (Ed.), The NNEST lens. New Castle: Cambridge Scholars Publishing, 2010. p.202-221.

ZIAEI, S. Examining Cross-Cultural Clues as to Globalization and Iran's Culture in an International ELT Book Series-American English File. Mediterranean Journal of Social Sciences. v.3, n.1, p. 143-148, 2012. 


\section{APPENDIX: Sample of questions used in the survey}

\section{SELF-PERCEPTION OF LANGUAGE ABILITY}

Compared to other non-native speakers of English in your country, how would you rate your command of English? Circle your answer. ( 5 is best.)

2. $3 . \quad 4 . \quad 5$.

If you think you have difficulties in the use of English, what are they? Describe them briefly.

On a scale from 1 to 5,5 being excellent and 1 being very low, how would you describe your level of proficiency in English in the following areas? Circle your answer.

Reading comprehension 12345

Writing/Composition 12345

Listening comprehension 12345

Speaking/ Oral communication 12345

Grammar accuracy in use 12345

Knowledge of grammar rules 12345

Breadth of vocabulary 12345

Pronunciation 12345

Is there any aspect of the English language that you find particularly difficult? Specify:

Do the language difficulties you experience represent a problem for your future work as a teacher of English? Circle your answer.

$\begin{array}{lllllll}\text { (very little) } & 1 & 2 & 3 & 4 & 5 & \text { (very much) }\end{array}$

PERCEPTIONS AS A (NON) NATIVE SPEAKER

As a (non) native speaker of English, what feelings related to the process of learning or teaching English have you had or do you have now?

\begin{tabular}{|r|l|l|}
\hline $\begin{array}{l}\text { Have you ever been concerned about } \\
\text { your accent as a non-native English } \\
\text { speaker? }\end{array}$ & YES & NO \\
Explain, why “yes" or why "no" : & & \\
\hline $\begin{array}{l}\text { As a non-native English speaker, } \\
\text { do you compare yourself to native } \\
\text { English speakers? } \\
\text { Explain, why "yes" or why "no" }\end{array}$ & YES & NO \\
\hline
\end{tabular}




\section{SELF-PERCEPTION AS A PROSPECTIVE NNEST}

What is the main reason why you want to become a teacher? Choose only one:

I liked teaching

I liked English

It was my best professional option

Others:

Which one of the following goals would better corresponds to yours if you already were a teacher of English?

To learn a high amount of language structures

To develop a high amount of communicative strategies

To know a high amount of communicative functions of the language

Others:

What English variety would you like your students to use?

A- British English

B- American English.

C- I would like them to be able to speak English efficiently for international communication, even though they speak with a Spanish accent, and they use a mixture of elements from British and American English.

D-Others:

What would be your biggest worry as an English teacher as regards not being a native speaker of the language you will teach?

A-not knowing the right answers

B- being caught in making mistakes

C-not being respected as a teacher/professional

D-not being able to advance in your career

E-feeling like you are chasing something impossible to achieve

F-being treated as a second class citizen in the job environment

What do you think can NSS English teachers who teach in Colombia contribute to their students? (choose a maximum of four items):

Higher confidence in the teacher and his/her adequacy to the job

A more active and innovative methodology

A good role model

More help to understand and adapt to the foreign language culture

More techniques to address learning difficulties

More knowledge of learning strategies for language learning

Higher awareness of students' sociocultural background

More attention to emotional and psychological issues 
What do you think can NS English teachers who teach in Colombia contribute to their students? (choose a maximum of four items):

Knowledge of a broader vocabulary

Acquisition of a better oral fluency

A more real and authentic atmosphere in class

More cultural information

Higher confidence in the teacher and his/her capacity for the job

A more active and innovative methodology

Acquisition of better pronunciation

Wider range of teaching resources

Others:

What do you think NNSs lack as compared to NS teachers? (choose a maximum of four items):

More fluency

More accuracy in oral language

More accuracy in written language

A higher preparation in the English teaching resources

A better knowledge of the culture(s) associated with the English language

Others:

What do you think NSs lack as compared to NNS teachers? (choose a maximum of four items):

Knowledge of the teaching environment and context

Preparation in linguistics and knowledge of grammar rules

Higher empathy with students

Knowledge of the EFL learning processes and strategies

A more active and innovative methodology

Knowledge of the local programs and educational currricula

A wider range of teaching resources

Intuition with regard to the areas where learners will experience difficulties

Capacity to mediate between the target and the learners' culture

A sensible use of $\mathrm{L} 1$ in the classroom

Others: 


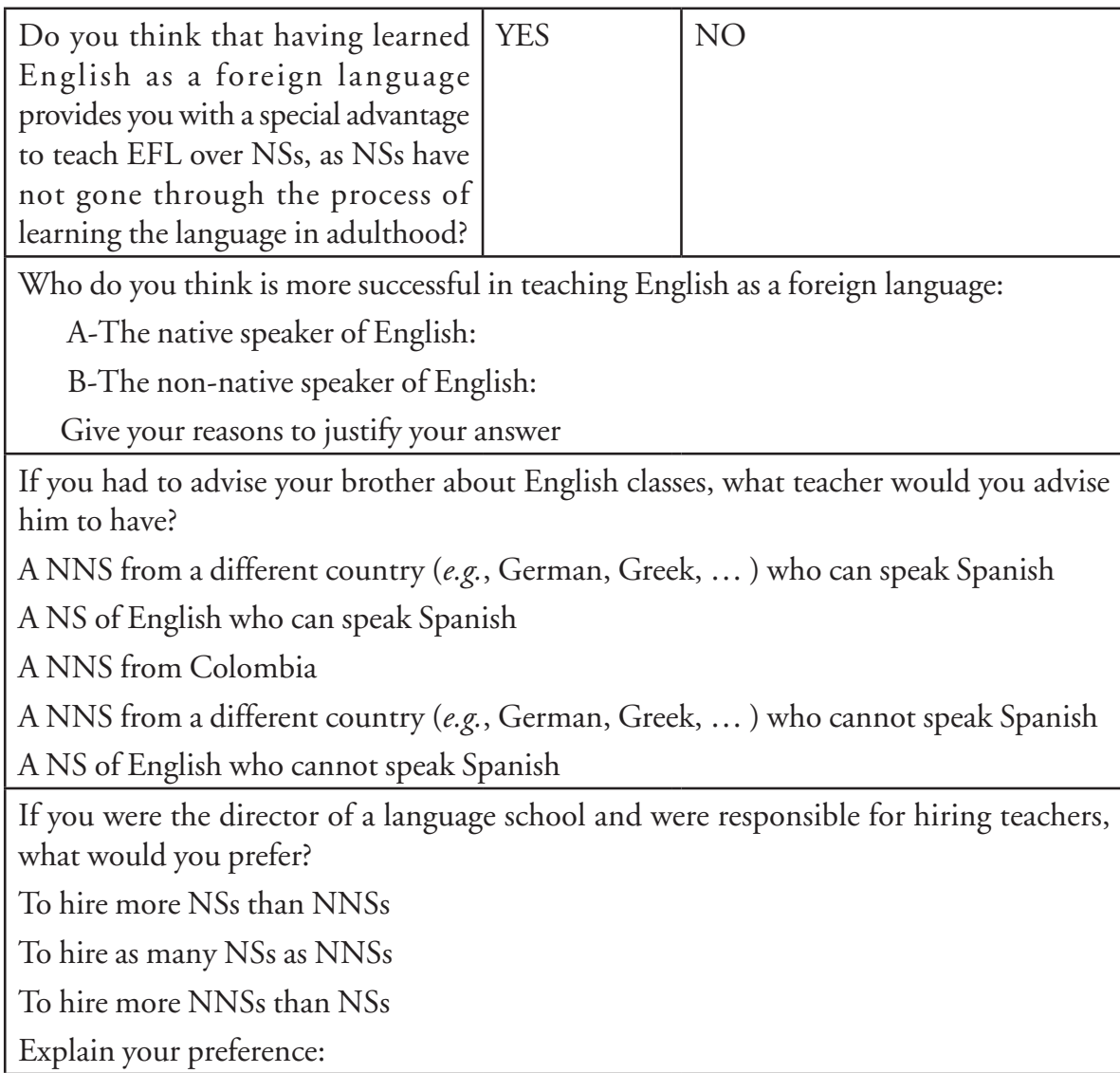

Data de submissão: 17/11/2015. Data de aprovação: 27/06/2016. 
